\title{
AUTOPOIESIS AS AN IMMANENT CREATIVE PROCESS OF THE ARTIST AND MUSICIAN
}

\section{Ohanezova-Hryhorenko O.}

\section{INTRODUCTION}

"We seek to analyze and understand the fundamental ways of thinking, comprehending, representing, imagining and reproducing in language, myth, art, religion, and even in science. We are no longer interested in individual art works, products of religious or mythological thinking; we are interested in those motor forces, the mental activity that is needed to create them"1. This statement of the philosopher and culturologist E. Cassirer emphasizes the main problem of modern art analysis, which, in our opinion, acquires a new quality precisely because it brings to the forefront of research the immanent component of the creative process. Modern art history analysis explains the origin and laws of the immanent creative process through the modern paradigms of the scientific worldview proposed by the development of the exact sciences, as well as through the use of natural history trends in the analysis of phenomena that are traditionally in the field of view of the humanities.

Taking into account the above-mentioned, we suggest exploring the professional personality of the artist and musician in line with the concept of autopoiesis of living systems and explaining the specifics of immanent creative processes, self-organization of the system through music and musical experiences.

\section{Phenomenology of autopoiesis of the living system}

Autopoiesis (from the Greek - myself + production, construction, creativity) - is a way of existence and development of complex structures (formations), allowing them to constantly produce and finish building themselves. The term was introduced by Chilean scientists Francisco Varela and Umberto Maturana in 1973 to reveal the essence of

${ }^{1}$ Кассирер Э. Лекции по философии и культуре // Культурология. ХХ век : антология / гл. ред. и сост. серии С.Я. Левит. М.: Юрист, 1995. 704 с. (Лики культуры). С. 147. 
living systems: their cyclical organization, autonomy, self-building and preservation of their identity in a changing environment ${ }^{2}$. Autopoiesis is self-organization of a living system.

U. Maturana and F. Varela sought to highlight the key feature of a living system. In their opinion, the essence of life is not the ability to reproduce, self-reproduce, as it is commonly believed, but the ability of a living system to maintain its identity. An autopoiesis system is built on the principle of self-attribution, a cyclical organization, it produces itself from itself. The spatial symbol of autopoiesis can be called a loop, as the quintessence of the process of returning to oneself.

As the most characteristic qualities of living systems, F. Varela and U. Maturana singled out the ability to self-production and sustainable development in their environment. Accordingly, the authors put forward the principle of operational isolation, autopoiesis continuity and spatial limitation $^{3}$. But, in the opinion of I. E. Moskalev, we are talking about a special kind of isolation, allowing the system to interact with the outside world and continuous self-development at the same time. On the one hand, something makes the system remain operationally closed with respect to the external environment (that is, maintain the basic life cycles and reproduce itself unchanged), and on the other hand, actively interact with the environment and use its challenges as a material and basis for self-organization already at a more advanced level. Thus, the ideas of cyclicality and circular causality in the context of autopoiesis acquired a new sound - as a description of sustainability, development and selfproduction at the same time 4 .

The function of autopoiesis is, firstly, the ability to constantly reproduce itself, and secondly, to maintain its autonomy with respect to the environment. Moreover, it is important that self-reproduction provides the active use by the system of external excitations as the lifegiving material of the process.

${ }^{2}$ Князева Е.Н., Курдюмов С.П. Основания синергетики. Синергетическое мировидение. Изд. 3-е, доп. М. : Книжный дом «Либроком», 2010. 256 с. (Синергетика: от прошлого к будущему). С. 18.

${ }^{3}$ Maturana H.R., Varela F.J. Autopoiesis and Cognition. The Realization of the Living. Dordrecht : D. Reidel, 1980.

${ }^{4}$ Москалев И. Е. Концепция автопоэзиса в современном научном познании [Электронный ресурс] : дис. ... канд. философ. наук: 09.00.08 . Москва, 2002. 141 c. URL : www.Synergetic.ru : 
The autopoiesis system owns a certain set of vital activity patterns, maintains its identity; it self-develops, self-reproduces, and remains resistant to the influence of external factors. This system is aimed at its own continuous updating and maintaining the integrity of its structure, therefore its sole purpose is to recreate itself. Thus, the most important characteristic of living systems is the ability to change its structure under the influence of external factors, but to remain the same system without losing organizational features - that means that the ability of living systems to constantly change is a condition for them to maintain their integrity and uniqueness 5 .

In this context, the main characteristic of living systems - the ability to self-organize - is clear. It must be emphasized that any processes in a living system are aimed only at autopoiesis. If the scheme is not implemented, the system is destroyed. A. A. Aredakov summarizes: "The concept of autopoiesis considers living as a system that exists in the eternal flow of substitutions of the material structure with the invariable form of the network - the invariability of the system pattern. The system pattern determines the cycles of its life, an algorithm of operations that allows it to reproduce itself» ${ }^{6}$.

The core characteristic of the living is the indissoluble connection of the system with the environment - E. N. Knyazeva and S. P. Kurdyumov explain it as a process occurring due to the structural interaction of the system and the outside world - their dynamic unity: "A complex system capable of self-organization is at the same time separated from the world and connected with it. Its boundary is similar to the membrane, which is the connection / separation boundary. The membrane allows the system to be open to the world, to take the necessary substances and information from the environment, and to be separate from it, in all its transformations and transformations, to maintain its integrity, to preserve its identity"7.

5 Ласицкая Э.В. Концепция автопоэзиса: бытие, познание, деятельность // Известия Саратовского университета. Серия: Философия. Психология. Педагогика. 2011. Т. 2, вып. 4. С. 14-16.

6 Аредаков А.А. Сознание в онтологиях антропного принципа // Вопросы философии. 2008. № 1. С. 45-50. С. 47.

7 Князева Е.Н., Курдюмов С.П. Основания синергетики. Синергетическое мировидение. Изд. 3-е, доп. М. : Книжный дом «Либроком», 2010. 256 с. (Синергетика: от прошлого к будущему). С. 216. 
In other words, the concept of autopoiesis considers the structural conjugation of the system and its environment as a continuous recurrent process of mutual disturbances between the system and the environment, compatible with the preservation of self-organization within a living system. In this context, it is important to note that the environment only initiates structural changes to the system, but does not specify them. Due to structural conjugation and operational isolation, the nervous system of a living organism works exclusively with internal correlations, and only they determine all the conditions of a living organism as a whole. The structural conjugation of the autopoiesis system determines the area of interaction into which it can enter. F. Varela and U. Maturana called this region as the cognitive region.

Taking this into account, we turn back to the semantic position in the concept of autopoiesis, which considers the issues of cognition from the point of view of the biological approach.

U. Maturana and F. Varela insist that the world is not given to be understood in its finished form: it is constructed by the cognitive system in the process of life. And the biological characteristics of a living organism determine the way of life - this position is fundamental. Scientists note: "All cognitive experience, including the cognitive on a personal level, is rooted in its biological structure» ${ }^{8}$.

Relying on the assertion that cognition has biological roots, and its results are determined by the physiology of the body, we affirm that the autopoiesis system "artist and musician" selects such an area of cognition - a type of communication that is a priori interesting to it, that is, defined by natural psychophysical inclinations. We find confirmation of our conclusions in the words of E. V. Lasitskaya: "The living system is in contact only with that part of its environment, which is the cognitive niche of this organism. The cognitive area in which it exists is determined by the autopoiesis of the system, so the area of cognition and living coincides» ${ }^{9}$. This conclusion is decisive in understanding the mechanism of choice by the system of its environment of life and development - its professional path.

8 Варела Ф., Матурана У. Древо познания. Биологические корни человеческого познания / пер. с англ. Ю.А. Данилова. М. : Прогресс-Традиция, 2001. 224 c. C. 14.

9 Ласицкая Э.В. Концепция автопоэзиса: бытие, познание, деятельность // Известия Саратовского университета. Серия: Философия. Психология. Педагогика. 2011. Т. 2, вып. 4. С. 15. 
The authors of the concept evaluate any interaction between the system and the environment as a cognitive act of the system. On the one hand, the environment has a resource that it uses to survive, self-support and self-creation of the body. On the other hand, the environment can pose a threat to the life of an organism in the form of its autonomy violation. Thus, the interaction of the system and the environment occurs as a fixation of challenges and the response of a living organism in a certain way, which, in fact, is a cognitive act.

The concept of autopoiesis develops within the framework of the evolutionary-synergetic paradigm, and this suggests that "the knower is rooted in the knowable, is one with him. He creates his world on the basis of physiological and cognitive capabilities, so knowledge takes on a "human-sized" character: in post-non-classical science, the world is given through man and his psychology"10. It is not for nothing that the visual image of the authors of the autopoiesis concept is Escher's drawing, depicting hands which are painting themselves. Thus, cognition of the environment (interaction with the environment) is carried out as a system of autopoiesis. According to E. N. Knyazeva, just such a view allows you to remove the «rigid subjective and objective construction of knowledge, based on the distance of the observer from the world ${ }^{11}$.

One of the most significant discoveries of recent times in the intellectual sphere is the discovery of an observer. The description of a living system is possible only from the point of view of a living system, which is the observer himself. In the concept of autopoiesis, the observer (the man himself) is a complex self-developing system that has the ability not only to self-production and renewal, but also selfreferentiality, working with his own descriptions as independent entities. There is no external reference; it means, there is no instance external to the system that can be consulted for a description of the system. A system is a self-describing structure. In other words, describing the technology of the creative process of the artist and musician, we simultaneously describe both the connections of the system with the outside world and the way of life of the system itself.

10 Ласицкая Э.В. Концепция автопоэзиса: бытие, познание, деятельность // Известия Саратовского университета. Серия: Философия. Психология. Педагогика. 2011. Т. 2, вып. 4. С. 16.

11 Князева Е.Н. Кибернетические истоки конструктивистской эпистемологии // Когнитивный подход : монография / отв. ред. В.А. Лекторский. М. : Канон+ ; РООИ «Реабилитация», 2008. 464 с. С. 261. 
The ability of the system to describe, analyze itself allows us to draw the following conclusion: the autopoiesis system proceeds from the properties of self-consciousness, which allows us to talk about the process of professional creativity as the action of the system in relation to the external environment in connection with the actions of the system in relation to itself, to its structure ${ }^{12}$.

Based on the above-mentioned, we can conclude that living systems are self-learning systems. Identifying the area of interaction - vital activity with the cognitive area, cognitive activity, F. Varela and U. Maturana come to the conclusion that «living systems are cognitive systems, and life as a process is a process of cognition $\rangle^{13}$. Talking about knowledge, F. Varela and U. Maturana understand «effective behavior in a given context» ${ }^{14}$. It is this area of adequate interaction between the system and the environment that allows to have autopoiesis in a living system.

The autopoiesis system does not display, but constructs reality, creates its own world, "cuts out" the layer of the world corresponding to its search activity and cognitive capabilities ${ }^{15}$. Thus, the structure of the autopoiesis system «artist and musician» is a reflection of its biological orientation in the choice of knowledge and activity.

The main mechanism of interaction between the system and the environment is communication. The German scientist N. Luman believes that communication is the main mechanism not only for interfacing the system and the environment, but also the mechanism by which the system distinguishes itself from the environment and also defines communication as an element and operation of the system ${ }^{16}$. In other words, the author considers communication as a specific language system that provides a structural union of internal processes of self-

12 Князева Е.Н., Курдюмов С.П. Основания синергетики. Синергетическое мировидение. Изд. 3-е, доп. М. : Книжный дом «Либроком», 2010. 256 с. (Синергетика: от прошлого к будущему).

${ }_{13}^{13}$ Maturana H.R. Biologieder Realitaet. F/M : Suhrkamp, 1998. P. 194.

14 Варела Ф., Матурана У. Древо познания. Биологические корни человеческого познания / пер. с англ. Ю.А. Данилова. М. : Прогресс-Традиция, 2001. 224 c. C. 153.

15 Князева Е.Н. Кибернетические истоки конструктивистской эпистемологии // Когнитивный подход : монография / отв. ред. В.А. Лекторский. М. : Канон+ ; РООИ «Реабилитация», 2008. 464 с. С. 267.

16 Луман Н. Социальные системы / пер. с нем. И.Д. Газиева; под ред. Н.А. Головина. СПб. : Наука, 2007. 648 с. 
organization in the system and the environment. Thus, relying on $\mathrm{N}$. Luman's understanding of the connection between communication and consciousness ${ }^{17}$, we note that the type of communication determines the mechanisms of its awareness and vice versa. This thesis is very important in understanding the conditions for the emergence of a professional process in the «artist and musician» system, which is carried out only if there is a certain natural task of the system - musical talent.

\section{Autopoiesis as a mechanism of the creative process}

Regarding the work of the artist and musician, communication - a way of communicating with the environment - is professional language - sound (timbral) impact. At the same time, the feeling of tonal changes in sound is a prerequisite for the implementation of the process of autopoiesis in the «artist and musician» system.

Autopoiesis as a mechanism of «creation», as a process of life and self-construction, best reflects the specifics of the artist's creative personality. M. A. Chekhov called this process «the creation of life». All the feelings, sensations, thoughts and actions of the artist are consciously and unconsciously aimed at creativity - at creating from his real personality a fictional musical image. In this process, not only a new living substance is born, but also the artist's personality is "created". In his book "The Way of the Actor" M. A. Chekhov regarded the artist's creativity as self-creation - the creation of his personality, the genesis of which consists of the possibility of "creativity within himself" for "creativity outside of himself"18.

We believe that any performing talent is an autopoiesis system, which assumes that the forces, abilities, specific qualities of intelligence, psychophysical properties of the body work in a mode of self-creation and self-improvement.

M. A. Chekhov insisted that performing art is a bizarre living fabric that includes a sense of the real world and sensory perception of this world in their unity, considered the highest point of stage creativity inspiration - as the ability of an artist to give his body to the flow of the creative process - an unconscious state, prepared and at the same time

17 Луман Н. Социальные системы / пер. с нем. И.Д. Газиева; под ред. Н.А. Головина. СПб. : Наука, 2007. 648 с.

18 Чехов М.А. Путь актера. М. : АСТ : Транзиткнига, 2003. 554, [6] с. (Мемуары). С. 62. 
controlled by conscious regulation. The most subtle connection between the conscious and the unconscious in the work of the creative apparatus is expressed, in our opinion, by the concept of "autopoiesis". The emphasis should be placed on the fact that the source of the unconscious for the creative person is not only "impersonal", but also the unconscious - the in-depth and produced by their sphere of collective unconscious.

In this context, it is appropriate to recall the concept of K.-G. Jung, who, unlike Z. Freud, did not consider psychology and imagery of thinking as a reflection of exclusively biological intentions. Images, in the understanding of K.-G. Jung, play the same important role as instincts, because to a large extent they carry archetypal elements. M. Y. Severinova also notes that it is a mistake to rigidly separate the personal and collective unconscious, because in order for the archetype as a «frame idea» to be able to «build up the flesh», a certain experience of life is necessary ${ }^{19}$.

The artist translates the meaning of primitives in a language that is understandable to modern man. The artist with the help of his living organism and the properties of his personality embodies the language of the unconscious on stage. According to M. Y. Severinova, artistic creativity, as a way of transforming psychic phenomena into phenomena of cultural life, through the unconscious turns to archetypal prototypes, leading them to turn into conscious values. Therefore, the archetypal core of the personality is not only the basis of creativity, but also its necessary component. Thus, according to the scientist, the creative process largely depends on the degree of immersion in the unconscious ${ }^{20}$.

A. F. Kosarev develops a similar idea: the scientist insists that in immersion to the unconscious we have the opportunity to observe the idea «not in the form of an abstract concept - this is the prerogative of

${ }^{19}$ Северинова М.Ю. Архетипи в культурі у проекції на творчість сучасних українських композиторів : дис. ... д-ра мистецтвозн. : 26.00.01 / НМАУ ім. П.І. Чайковського. Київ, 2013. 415 с. С. 86.

${ }^{20}$ Северинова М.Ю. Архетипи в культурі у проекції на творчість сучасних українських композиторів : дис. ... д-ра мистецтвозн. : 26.00.01 / НМАУ ім. П.І. Чайковського. Київ, 2013. 415 с. С. 90. 
logical thinking, but in the form of sensory - such that is seen, such that is heard - an image (image-meaning)» ${ }^{21}$.

In the context of research issues, we rely on the positions of scientists in order to accentuate understanding of autopoiesis as a process of conscious and unconscious informatively-sensual exchange, which is the basis and at the same time the mechanism of the creative process of the artist and musician, because, according to a famous psychologist, a researcher of specific features of a creative person N. F. Rozhdestvenskaya, «in the creative mind, knowledge, experience and attitude are combined into one» ${ }^{22}$.

As you know, a person has the opportunity to gain knowledge about the world not only through his practical experience, but also through spiritual experience, from himself, from his consciousness and subconscious. It is this phenomenon that largely explains the artist's ability to experience on stage and convey to the viewer those emotions that were not experienced in real life. On the one hand, this is the merit of fantasy as the primary creative ability, and on the other, this is the genetic stock of the unconscious experienced by man in the broadest sense of the word. After all, as A. G. Vasadze claimed, the unconscious sphere of the psyche «is a sphere belonging and entering into the structure of the artist's personality» ${ }^{23}$. Art is literally permeated with the activity of the unconscious at all levels, from the most elementary to the highest ${ }^{24}$.

Given the general specificity of the creative process of the artist and musician, the concept of autopoiesis can be used to understand the processes of consciousness, since it indicates the unity of cognitive and creative functions. In this sense, we understand autopoiesis as a certain form of consciousness that allows the system to evolve to a complex

21 Косарев А.Ф. Философия мифа : Мифология и её эвристическая значимость : учеб. пособие для вузов. М. : ПЕР СЭ ; СПб. : Университетская книга, 2000. 304 с. С. 84.

22 Рождественская Н.Ф. Психология художественного творчества: учеб. пособие. СПб. : Языковой центр филол.ун-та Санкт-Петерб.гос. ун-та, 1995. 270 c. C. 27.

${ }^{23}$ Васадзе А.Г. Проблема художественного чувства. Тбилиси : Мецниереба, 1978. 174 c. С. 95.

24 Бессознательное: Природа. Функции. Методы Исследования : в 4 т. Тбилиси : Мецниереба, 1978. Т. 2. 688 с. С. 478. 
cognitive system that owns a developed consciousness ${ }^{25}$. According to E. N. Knyazeva "the auto-poetry of the consciousness work is its continuous self-production, its maintenance of its identity through its constant search and its formation. In autopoiesis there is always not only the preservation of the state, but also its overcoming, updating, ${ }^{26}$. Thus, we understand the autopoiesis of the artist and musician as a creative state of his consciousness, which implies the existence of a vector for self-construction, invention and construction, achievement of goals and building integrity ${ }^{27}$. F. Varela's thought is important in this context: the scientist emphasizes that in its essence, cognition (in our context, the creative process) is autopoiesis - "it is aimed at finding what is missing and filling out the missing cognitive agent from the point of view"28. Thus, autopoiesis of consciousness can be interpreted as the ability of the system to maintain its autonomy with respect to the external environment, depending on the level of self-organization, a quality that allows the system to maintain its identity and individuality even in conflict with the environment.

So, we understand the autopoiesis of the consciousness work of the artist and musician as a way of self-organization of an autopoiesis system that allows cognitive and creative functions of consciousness to manifest itself, it is such a quality of co-evolution of the artist's consciousness and environmental challenges that enables the system to reach an attractor, an acme, a psychological indicator of which for a creative person is experiencing catharsis.

Summing up, we emphasize that the concept of autopoiesis allows to describe and analyze a living system - the artist and musician in terms of a professional creative algorithm. Also, the concept of autopoiesis opens up possibilities for analyzing the work of the psychophysical apparatus of the artist and musician in a cognitive aspect - in terms of organizing a

25 Ласицкая Э.В. Концепция автопоэзиса: бытие, познание, деятельность // Известия Саратовского университета. Серия: Философия. Психология. Педагогика. 2011. Т. 2, вып. 4. С. 14.

${ }^{26}$ Князева Е.Н., Курдюмов С.П. Основания синергетики. Синергетическое мировидение. Изд. 3-е, доп. М. : Книжный дом «Либроком», 2010. 256 с. (Синергетика: от прошлого к будущему). С. 217.

${ }^{27}$ Князева Е.Н., Курдюмов С.П. Основания синергетики. Синергетическое мировидение. Изд. 3-е, доп. М. : Книжный дом «Либроком», 2010. 256 с. (Синергетика: от прошлого к будущему). С. 216-217.

${ }^{28}$ Varela F.J. Patterns of Life: Intertwining Identity and Cognition // Brain and Cognition. 1997. Vol. 34. P. 85. 
professional algorithm and establishing the specifics of natural psychic and psychological characteristics that help to establish certain galaxies of abilities during the period of professionalization. Such an analysis (introspection) opens up opportunities in understanding the strengths and weaknesses of one's talent, in building the right career growth strategy, respectively, in the possible achievement of acme.

\section{Creative dominant - a parameter of the autopoiesis system order}

In other words, self-organization (autopoiesis) acts as a constructive, ordering mechanism for the evolution of the personality of the artist and musician as a professional. The ability to self-organize (self-regulation) is one of the most important indicators of professional suitability.

A living organism is that self-organizing system that constantly goes into a critical mode by its very nature, as a result of its inherent internal tendencies of evolution. The critical states of such systems do not require fine tuning of external control parameters and, in fact, have the property of self-support ${ }^{29}$. We are interested in the following: what is the source of such self-support?

Since we consider the psychophysical apparatus of the artist and musician as a self-organizing system, it is important to highlight the order parameter of this system. According to the synergistic concept, the concept of an order parameter helps to understand and describe the principles of system behavior, its hierarchical levels, main and secondary segments, and the nature of their interaction. The concept of "order parameter" was introduced by the German scientist G. Haken as a factor determining the degree and quality of influence on a system at a dynamic level, a factor to which the behavior of all elements of the system is subordinate $^{30}$.

The most informative element of the self-organizing system «artist and musician» is, in our opinion, the creative dominant - the constant natural need for creative activity inherent in its psychophysical organization. As M. P. Blinova writes, "For a productive creative

${ }^{29}$ Евин И.А. Искусство и синергетика. М. : Едиториал УРСС, 2004. 164 с. C. 12 .

${ }^{30}$ Князева Е.Н., Курдюмов С.П. Основания синергетики. Синергетическое мировидение. Изд. 3-е, доп. М. : Книжный дом «Либроком», 2010. 256 с. (Синергетика: от прошлого к будущему). С. 211. 
process, long-term support for optimal arousal, that is, the presence of the so-called dominant» ${ }^{31}$.

Dominant (from lat. dominaus - ruling, dominant) - determines the direction of behavior and thinking. According to A. A. Ukhtomsky, who proposed the term and developed the doctrine of the dominant, the dominant is the main emotional and psychological need of the individual; it is not only the normal working principle of singing centers, but it also plays a significant role in the process of neoplasms of reactions to the environment. According to the scientist, it is the dominant that ensures the organism's adaptation to the environment, its survival, and, if necessary, the transformative effect on the environment. The dominant increases the power of the system itself and becomes the material basis for its long-term adaptation to the challenges of the external environment ${ }^{32}$.

I. A. Evin considers principle of dominant by A. A. Ukhtomsky for nervous activity similar to the principle of submission in the processes of self-organization, where the creative dominant itself performs the function of an order parameter. In his opinion, thanks to the creative dominant a universal and same description of any creative system can be realized.

Confirmation of the importance of creative dominant for the maintenance and self-organization of the artist as an autopoiesis system is found in Y. M. Shor, who presents the artist as the most complicated synthesis of psychophysical and social, on the border of which the specificity of his personality arises: "An artist is distinguished from a non-artist by the main dominant focus on aesthetic activity, on the creation of artistic images, on the transformation of his mental world into an aesthetic world. As soon as this activity begins, a transformation takes place, mental processes are grouped around a super-task, begin to work as moments of higher integrity, become elements of an artistic system» ${ }^{33}$. It is the creative dominant that makes us consider all external events and

31 Блинова М.П. Музыкальное творчество и закономерности высшей нервной деятельности / Ленингр. гос. ин-т театра, музыки и кинематографии. Л. : Музыка, Ленингр. отд-е, 1974. 142 с. С. 20.

32 Ухтомский А.А. Доминанта. СПб. : Питер, 2002. 448 с. (Серия : «Психология - классика»). С.59.

33 Диагностика и развитие актерской одаренности : сб. науч. тр. / Ленинградский государственный институт театра, музыки и кинематографии им. Н.К. Черкасова. Л., 1986.155 с. С. 8. 
changes in the internal states of the artist and musician through the prism of their usefulness for the creative process. Experienced artists know that they collect any event of life, any act, any reaction of others, and, most importantly, the reaction of their psychophysical apparatus to this, into an "emotional box". This is the material from which artists "breathe life" into fictional musical images through reservoirs of emotional memory. The timbre palette of the image, the plastic features of the performance, etc. manifestations - all this material is born of the imagination of the creator, feeding on the experience of life. This feature of the artistic personality nature, in our opinion, is eloquently reflected in the concept of dominant: "Dominant is a disturbed, loosened place of the nervous system, a kind of "shooting", to which all necessary and unnecessary sticks, from which then the selection of what is enriched experience is done",34.

It should be noted that the artist, thanks to the power of creative dominant, is able to withstand any tests by the outside world - both positive and negative. For example, if the field of life of the autopoiesis system "artist and musician" is a professional musical composition that meets the needs of a creative dominant, then lack of money, for example, will not force it to change its occupation. The response to the challenge is rather not a change of profession, but more intense professional work and / or more aggressive behavior in the corporate environment. Thus, one can speak of creative dominant as a vital determining condition for the evolution of the autopoiesis system.

It should also be noted that the creative dominant is capable of changing its strength depending on objective circumstances - the possibility or impossibility of realizing a person in a given profession, in a given place, at given time; as well as subjective circumstances accentuation of the personality, level of talent, some of the innate mental qualities of the psychophysical organization, which either help in overcoming environmental challenges or not. But it is always the creative dominant that is capable of blocking by force and significance all other dominants.

In other words, we can talk about the creative dominant as an internal spring, a kind of "energy block" that forces the creative powers of the creator's consciousness to develop, enrich, and compete. Without a

${ }^{34}$ Ухтомский А.А. Доминанта. СПб. : Питер, 2002. 448 с. (Серия : «Психология - классика»). С. 105. 
sufficiently intense dominant, the makings of the body are simply not able to develop to a professional level. Thus, we can conclude that the presence of creative dominant is a kind of manifestation of the creative talent of the person, which, next to natural inclinations, determines the nature of the activity. The intensity of the creative dominant, which determines a person's devotion to his life's creative choice, is the most important special ability of his psychophysical apparatus.

Mental capacity, psychological endurance, "charged" with a creative dominant, help to go through all the tests of the external environment. The desire to stay at a competitive level in a professional corporation can be one of the factors that enhance creative dominant. Conversely, a decline in the desire to compete in the profession is a signal of the decay of the creative dominant.

Based on the postulates of the concept of autopoiesis of living systems, we consider the creative process as the cognitive activity of the system. And, according to the concept of autopoiesis, the cognitive area of a system's activity is determined by its biological organization: for the artist and musician, the content of a creative dominant is determined by the musical specificity of its talent, which predicts professional skills and technological algorithms.

In this context, the dominant role in the successful implementation of technological processes inherent in the work of the artist and musician is indicative: the competencies of the creative profession are a merit of consciousness, but many, even the technological moments of assimilation of musical material, are on the border of conscious and unconscious processes. The connection of consciousness and subconsciousness, intuitive insights inherent in the creative process, basically contain a creative dominant that drives the entire process of production of a creative product, playing the role of "fuel" in the process of self-organization of a professional creative person.

In the context of understanding the creative dominant as a "fuel" in the process of autopoiesis of a creative person, we turn to P. V. Simonov and P. M. Ershov, who consider the dominant as absorbing a person's determination, forming the "ultimate task of life" "35, which I. P. Pavlov called the «goal reflex» 36 .

35 Симонов П.В., Ершов П.М. Темперамент. Характер. Личность. М. : Наука, 1984. 160 с.

36 Симонов П.В., Ершов П.М. Темперамент. Характер. Личность. М. : Наука, 1984. 160 с. С. 101-102. 
An indicator of a person's presence of a powerful practical (in our case, creative) dominant, according to P. V. Simonov and P. M. Ershov, is the activity of superconsciousness (creative intuition). Scientists propose to consider the three levels of the psyche - the subconscious, conscious, superconscious - as a parameter of individuality, since the activity of these three instances is far from equally expressed in different people. Obviously, this combination determines the degree of creative giftedness of a person. A dominant need mobilizes all available human capabilities. If at the same time super-consciousness (which begins to work involuntarily) is not included in the work, then this means that the dominant is not affected. Intuition works only where the dominant personality is affected: "The search for a solution (satisfying a need) is first limited to the activity of consciousness and the sub-consciousness. But as more and more new obstacles increase in the path to dominant satisfaction, so does the effort. Reserves available to consciousness are increasingly mobilized, starting with previously proven means. Then the person moves on to the first methods used, to the search for new tools, to modeling, suggestions, conjectures: intuition begins to work. Such a gradual mobilization of efforts is a means of saving the body's strength. And if the energy impulse of need is strong, then super-consciousness is able to suggest an intuitive solution. Its productivity is determined by the degree of armament" ${ }^{, 37}$ (the presence of professional skills - O. O.-H.). Thus, we can conclude that the mechanisms of super-consciousness (in our case, creative intuition) are included in that need, which is the main one that determines the structure of motives of a given person, for the artist and musician - creative dominant.

In our opinion, creative intuition (super-consciousness) is a certain alloy of conscious efforts and reserves of the unconscious, which open up a significant part of information in the creative process. This state most accurately reflects the description of the nuclear reaction, when the energy generation itself occurs on the basis of the "accumulated temperature" of consciousness, which already lacks the "fuel" of conscious resources. "Intuition (Simonov and Ershov call it superconsciousness $-O$. O. $-H$.) is included where the motivational dominant is encountered with information deficit, with a break in the logical chain

37 Симонов П.В., Ершов П.М. Темперамент. Характер. Личность. М. : Наука, 1984. 160 с. С. 101-102. 
of thinking and action» ${ }^{38}$. In other words, if there is a lack of information resources in the sphere of consciousness, it is the creative dominant that "turns on" the reserves of the unconscious.

One of the convincing manifestations of an artist's creative dominant is «a generous expenditure of energy, since the dominant forces one to overcome the need for their savings $\gg{ }^{39}$. People in creative professions are well aware of the state of spiritual and mental stress that accompanies the birth of a stage image, musical or literary composition, and other products of creativity. This tension persists for a long time, for 24 hours a day, while the body forces are consumed with great intensity. Artists call this state "Tortures of creativity", but history does not know a single example of a voluntary rejection of these "tortures".

Based on the above-mentioned studies, we can conclude that only with the presence of creative dominant in the personality structure of the artist can his professional life be realized. The need for creative activity a creative dominant - is a motivating factor for the self-organization of the artist and musician, and the intensity and success of the process depend on the embodiment of the creative dominant in professional actions. According to I. A. Evin, «Art deals with those striving for support, for the repetition of the needs and feelings of a person, when the satisfaction of these feelings restores the need for them» ${ }^{40}$. The act of satisfying the artist's need for stage activity will result in a temporary weakening of his energetic mental stress, the so-called "release of steam", which does not mean weakening of the creative dominant, on the contrary, the act of "releasing steam" even "inflames" the creative dominant, the artist wants to experience this state over and over. The need for professional creative activity as a vital dominant "survives" both with a successful result and a failure; the positive charge of a successful action is a feeling of joy, satisfaction, the negative charge of a failed action is anger, rage, envy. Causing a different degree of excitement, with a different charge, the creative dominant ("creative itching") almost never fades and does not "release" its master into the normal, calm life of the usual man.

38 Симонов П.В., Ершов П.М. Темперамент. Характер. Личность. М. : Наука, 1984. 160 с. С. 96.

${ }^{39}$ Симонов П.В., Ершов П.М. Темперамент. Характер. Личность. М. : Наука, 1984. 160 с. С. 105.

40 Евин И.А. Искусство и синергетика. М. : Едиториал УРСС, 2004. 164 с. C. 50. 
The concept of dominant is a universal general biological principle that underlies the activity of all living things. The life of the artist and musician is based on a subconscious desire for creative activity that drives him throughout his life, from childhood onwards, determining the choice of a profession and predicting the intensity and effectiveness of implementation in it. Thus, the creative dominant is the core around which the entire personality structure of the artist and musician and his life system are built. It can be argued that for the autopoiesis system «artist and musician» the creative parameter is precisely the order parameter.

\section{CONCLUSIONS}

Analysis and systematization of modern research in the field of synergetic worldview allowed us to consider the phenomenology of the creative process of the artist and musician as autopoiesis of a living system. We study the personality of an artist and musician as an autopoiesis system; we understand the inherent creative process as an autopoiesis process.

The concept of autopoiesis can be applied to understand the creative form of consciousness that allows the system to evolve. We interpret autopoiesis of the work of the artist and musician's consciousness as a way to self-organize the system, allowing cognitive and creative functions of consciousness to manifest them. This gives the potential to achieve the most significant results in creative activity.

We consider the creative dominant to be the «energy source» for the development of a living autopoiesis system, which most accurately characterizes the formation features of reactions to environmental challenges and the direction of the processes in the system. Thus, the creative dominant confirms its characteristics of the order parameter the most informative element of the autopoiesis system, which is preserved under any circumstances and determines the direction of the system evolution.

\section{SUMMARY}

The article proposes to analyze the creative personality of an artist and musician from the standpoint of the concept of autopoiesis of living systems. This approach is justified by the fact that the autopoiesis of a living system is self-organization aimed at the evolution of a living system while maintaining its integrity and uniqueness, as well as the biological justification of the process of autopoiesis, its orientation and 
characteristic features. The autopoiesis approach in describing the creative personality and the process of creativity itself allows us to analyze the artist and musician as a living system, the biological characteristics of which determine the direction and nature of selforganization; creativity - as a process of consciously unconscious autopoiesis; creative dominant - as the order parameter of the autopoiesis system, which is the engine in the system evolution to the highest results.

\section{REFERENCES}

1. Maturana H.R., Varela F.J. Autopoiesis and Cognition. The Realization of the Living. Dordrecht : D. Reidel, 1980.

2. Varela F.J. Patterns of Life: Intertwining Identity and Cognition // Brain and Cognition. 1997. Vol. 34.

3. Аредаков А.А. Сознание в онтологиях антропного принципа // Вопросы философии. 2008. № 1. С. 45-50.

4. Бессознательное: Природа. Функции. Методы Исследования : в 4 т. Тбилиси : Мецниереба, 1978. Т. 2. 688 с.

5. Блинова М.П. Музыкальное творчество и закономерности высшей нервной деятельности / Ленингр. гос. ин-т театра, музыки и кинематографии. Л. : Музыка, Ленингр. отд-е, 1974. 142 с.

6. Варела Ф., Матурана У. Древо познания. Биологические корни человеческого познания / пер. с англ. Ю.А. Данилова. М. : Прогресс-Традиция, 2001. 224 с.

7. Васадзе А.Г. Проблема художественного чувства. Тбилиси : Мецниереба, 1978. 174 с.

8. Диагностика и развитие актерской одаренности : сб. науч. тр. / Ленинградский государственный институт театра, музыки и кинематографии им. Н.К. Черкасова. Л., 1986. 155 с.

9. Евин И.А. Искусство и синергетика. М. : Едиториал УРСС, 2004. $164 \mathrm{c}$.

10.Кассирер Э. Лекции по философии и культуре // Культурология. ХX век : антология / гл. ред. и сост. серии С.Я. Левит. М. : Юрист, 1995. 704 с. (Лики культуры).

11.Князева Е.Н. Кибернетические истоки конструктивистской эпистемологии // Когнитивный подход: монография / отв. ред. В.А. Лекторский. М. : Канон+ ; РООИ «Реабилитация», 2008. 464 с.

12.Князева Е.Н., Курдюмов С.П. Основания синергетики. Синергетическое мировидение. Изд. 3-е, доп. М. : Книжный дом «Либроком», 2010. 256 с. (Синергетика: от прошлого к будущему). 
13. Косарев А.Ф. Философия мифа : Мифология и её эвристическая значимость : учеб. пособие для вузов. М. : ПЕР СЭ ; СПб. : Университетская книга, 2000. 304 с.

14. Ласицкая Э.В. Концепция автопоэзиса: бытие, познание, деятельность // Известия Саратовского университета. Серия: Философия. Психология. Педагогика. 2011. Т. 2, вып. 4. С. 14-16.

15. Луман Н. Социальные системы / пер. с нем. И.Д. Газиева ; под ред. Н.А. Головина. СПб. : Наука, 2007. 648 с.

16. Москалев И. Е. Концепция автопоэзиса в современном научном познании [Электронный ресурс] : дис. ... канд. философ. наук: 09.00.08 . Москва, 2002. 141 c. URL : www.Synergetic.ru:

17. Рождественская Н.Ф. Психология художественного творчества: учеб. пособие. СПб. : Языковой центр филол.ун-та Санкт-Петерб.гос. ун-та, 1995. 270 с.

18. Северинова М.Ю. Архетипи в культурі у проекції на творчість сучасних українських композиторів: дис.... д-ра мистецтвозн. : 26.00.01 / НМАУ ім. П.І. Чайковського. Київ, 2013. $415 \mathrm{c}$.

19. Симонов П.В., Ершов П.М. Темперамент. Характер. Личность. М. : Наука, 1984. 160 с.

20. Ухтомский А.А. Доминанта. СПб. : Питер, 2002. 448 с. (Серия : «Психология - классика»).

21. Чехов М.А. Путь актера. М. : АСТ : Транзиткнига, 2003. 554, [6] с. (Мемуары).

Information about the author: Ohanezova-Hryhorenko O., Doctor of Arts, Professor at the Department of Solo Singing, Odessa National A. V. Nezhdanova Academy of Music 63, Novoselskogo str., Odessa, 65023, Ukraine 